\title{
Agro-meteorological indices of aromatic rose (Rosa damascena Mill.) influenced by pruning time in the western Himalayas
}

\author{
MEENAKSHI THAKUR and RAKESH KUMAR \\ ${ }^{2}$ Academy of Scientific and Innovative Research, CSIR-Institute of Himalayan Bioresource Technology \\ Post Box No. 6, Palampur 176061 (HP), India \\ *Corresponding Author,Email: rakeshkumar@ihbt.res.in
}

\begin{abstract}
A field experiment was conducted during 2015-2017 at CSIR-Institute of Himalayan Bioresource Technology, Palampur, India to calculate agro-meteorological indices and to study the duration of different phenological phases of damask rose (Rosa damascena) varieties under mid hills of western Himalayas. Agro-meteorological indices were computed for two damask rose varieties Himroz and Jwalaat different pruning time from October 30 to January 15 at fifteen days' interval. The results indicated that the number of days required forattaining each phenological stage, decreased with delay in pruning time. Variation in different phenological stages of damask rose varieties were observed. Higher GDD, PTU and HTU were accounted by Jwala as compared to Himroz during all the phenophases of $R$. damascena. Plants pruned on January 15 (late pruning) required lesser GDD, PTU as well as HTU, while plants pruned on October 30 (early pruning) accumulated higher GDD, PTU and HTU during crop growth period. The results showed that agro-meteorological indices play a vital role in the productivity of $R$. damascenacrop.
\end{abstract}

Keywords : Pruning time, growing degree days, photothermal unit,helio-thermal unit.

Roses are believed to be pruned every year regularly for proper growth and development and it increases the aesthetic values like the quality of the flowers and larger blooms with inspiring color. Pruning in roses not only ease the harvesting of flowers, but also maintain the plant in proper shape and other intercultural operations. Beside this, morphological and yield parameters in roses are also affected by pruning. Like in ornamental rose, pruning has been found to be fruitful in aromatic rose (Zekavati, 2013).

Crop weather relationship studies in aromatic plants are very meager and need attention. GDD or heat unit requirement has often been used for characterizing thermal responses in crops but no attempt has been made to study its response in damask rose. Though some attempts earlier have been made for medicinal and aromatic crops viz., wild marigold (Kumar et al., 2010), clary sage (Personnel communication), stevia (Kumar et al., 2010) and mentha (Braret al., 2015). The objective of the present study was to ascertain the role of meteorological parameters in crop growth and development of $R$. damascena varieties under mid hill conditions of western Himalayas.

\section{MATERIALS AND METHODS}

\section{Field experiment}

To perceive the thermal impact on different phenophases and productivity of $R$. damascena, field experiment was carried out for two years during 2015-2017 at the medicinal and aromatic plants research farm of CSIRInstitute of Himalayan Bioresource Technology, Palampur (1390 m amsl, 32 $\left.06^{\prime} 05^{\prime \prime} \mathrm{N}, 76^{\circ} 34^{\prime} 10^{\prime \prime} \mathrm{E}\right)$, India. The soil of the experimental area is clay loam in texture, high in organic carbon (1.0\%), acidic in reaction ( $\mathrm{pH} 5.7$ ), medium in available $\mathrm{N}\left(278.4 \mathrm{kgha}^{-1}\right)$, available P $\left(17.2 \mathrm{kgha}^{-1}\right)$ and available K $\left(275.4 \mathrm{kgha}^{-1}\right)$. The experiment was designed based on split plot design with four replications. The field experiment consists of two varieties (Himroz and Jwala) in the main plot and six pruning times (October 30 , November 15 , November 30, December 15, December 30 and January 15) in subplots. Phenological parameters viz., days taken for pruning to leaf bud formation, days taken for leaf bud to flower bud formation, days taken for flower bud to flower initiation, days taken for flower initiation to complete flower harvestand total days taken for pruning to complete flower harvest were recorded during the cropping period. Fresh flowers of damask rose were plucked early in the morning daily before sunrise during the flowering season. The damask rose plants used for these studies were transplanted in August 2008 at a spacing of $1.50 \mathrm{~m} \times 0.75 \mathrm{~m}$ from row to row and plant to plant, respectively.

Data on weather parameters viz., maximum, minimum 


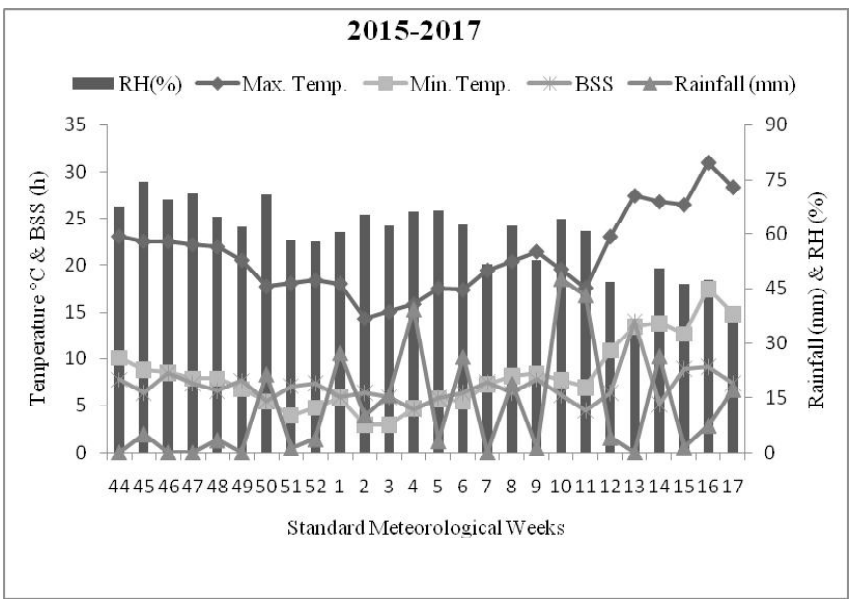

Fig 1: Standard meteorological weeks during the cropping season of $R$. damascena (Pooled data of two years).

temperature, rainfall, bright sunshine hours, daylength and relative humidity $(\mathrm{RH})$ used for the study were recorded from meteorological observatory of the C. S. K. Himachal Pradesh Agricultural University, Palampur, H.P. The agrometeorological indices viz., GDD, PTU and HTU were calculated by using the standard formulas (Kumar et al., 2012) for different phenophases of $R$. damascena. For calculation of GDD, PTU and HTU base temperature was taken as $5.2^{\circ} \mathrm{C}$ (Mattson and Lieth, 2007). The recorded data were analyzed with analysis of variance (ANOVA) procedures using the Statistical Software Package (SAS 9.1) and used excel software to draw graphs.

\section{RESULTS AND DISCUSSION}

\section{Crop phenology}

Phenophase development of the plant is affected by the environment. Development of phenological stage is an important component of crop weather relationship studies of damask rose. During crop growing season maximum temperature was within the range of 14.2 to $30.9^{\circ} \mathrm{C}$ and minimum temperature ranges between 2.8 to $17.5^{\circ} \mathrm{C}$, respectively (Fig. 1). The calendar of different phenological stages for damask rose wasinfluenced by different pruning time for two different varieties Himroz and Jwala. The number of days taken by the damask rose crop for completion of each phenophase varied with different pruning time (Table 1). The number of days for each phenological stage decreased with the delay in pruning from October 30 to January 15. The delayed pruning reduced the length of all phenological stages significantly. Among the different pruning times, early pruned plants (October 30 ) took significantly higher number of days for each phenological stage viz., pruning to leaf bud formation (25.7 days), leaf bud to flower bud formation (110.1 days) and flower bud to flower initiation (25.4 days), however, unequal days were observed from flower initiation to complete flower harvest.Late pruning (January 15) took significantly lesser number of days for each phenological stage viz., pruning to leaf bud formation (18.1 days), leaf bud to flower bud formation (54.0 days) and flower bud to flower initiation stage (12.6 days).A similar trend was observed for pruning to complete flower harvest stage, October 30 pruning took significantly higher number of days (184.9 days) as compared to subsequent pruning time. However, January 15 pruned plants completed vegetative and flowering (pruning to complete flower harvest) with significantly lesser number of days (111.6 days) (Table 1). The significant differences were observed in damask rose varieties for each phenological stage. Variety Jwala took significantly higher number of days for each phenological stage viz., pruning to leaf bud formation ( 23.5 days), leaf bud to flower bud formation (56.5 days), flower initiation to complete flower harvest (26.0) and pruning to complete flower harvest (151.0 days). However, variety Jwala took lesser number of days for stage flower bud to flower initiation (Table1). These results were closely related to the findings of Kumar et al., (2008) which showed a number of days gradually reduced by delay in sowing soybean. Late pruning induced early flowering in damask rose crop, due to increased day length along with temperature variations. Late pruned crop reduced the duration of the vegetative period due to the alteration of temperature and rainfall. VarietyJwala took significantly higher number of days to complete each phenological stage compared to Himroz variety; this may be because of genetic makeup of the variety.

\section{Growing degree days}

Accumulated thermal unit presented in Table 2 showed lowest accumulated heat units $\left(476.8\right.$ and $536.5^{\circ} \mathrm{C}$ days)for January 15 pruning. Variety Jwala accumulated more heat units to complete each phenological stage as compared to variety Himroz. Accumulated heat units consumed for pruning to completion of the vegetative period were maximum in October 30 . The result presented in Table 2 showed that varieties Himroz and Jwala took 1363.0 and $1441.1^{\circ} \mathrm{C}$ days for early pruned plant (October 30)and 823.9 and $842.6^{\circ} \mathrm{C}$ days for late pruned plants (January 15), respectively. Among the two varieties, Jwala observed maximum GDD for each phenological stage as compared to variety Himroz. This was due to longer time period for all the phenological stages in the early pruning. Late pruning decreased the duration of 
Table 1: Days taken for completion of different phenological stages of $R$. damascena varieties as influenced by pruning time (Pooled data of two years).

\begin{tabular}{|c|c|c|c|c|c|}
\hline Treatment & $\begin{array}{l}\text { Pruning to } \\
\text { leaf bud } \\
\text { formation }\end{array}$ & $\begin{array}{l}\text { Leaf bud to } \\
\text { flower bud } \\
\text { formation }\end{array}$ & $\begin{array}{l}\text { Flower bud to } \\
\text { flower initiation }\end{array}$ & $\begin{array}{l}\text { Flower } \\
\text { initiation to } \\
\text { complete flower } \\
\text { harvest }\end{array}$ & $\begin{array}{l}\text { Pruning to } \\
\text { complete } \\
\text { flower } \\
\text { harvest }\end{array}$ \\
\hline \multicolumn{6}{|l|}{ Variety } \\
\hline Himroz & 21 & 51 & 15 & 20 & 144 \\
\hline Jwala & 23 & 56 & 10 & 26 & 151 \\
\hline $\mathrm{SEm} \pm$ & 0.3 & 0.2 & 0.5 & 1 & 0.4 \\
\hline $\mathrm{CD}(\mathrm{p} \leq 0.05)$ & 0.2 & 0.7 & 2 & 5 & 4.8 \\
\hline \multicolumn{6}{|l|}{ Pruning Time } \\
\hline October 30 & 25 & 110 & 25 & 22 & 184 \\
\hline November 15 & 23 & 104 & 18 & 21 & 168 \\
\hline November 30 & 22 & 92 & 16 & 23 & 155 \\
\hline December 15 & 21 & 81 & 13 & 23 & 140 \\
\hline December 30 & 19 & 69 & 12 & 23 & 125 \\
\hline January 15 & 18 & 54 & 12 & 26 & 111 \\
\hline $\mathrm{SEm} \pm$ & 0.2 & 0.7 & 0.9 & 0.7 & 1.8 \\
\hline $\mathrm{CD}(\mathrm{p} \leq 0.05)$ & 0.7 & 2.2 & 2.5 & 1.8 & 1.2 \\
\hline
\end{tabular}

Note: CD: Critical Difference; SEm; Standard Error of Mean; NS: Not significant

phenology as compared to early pruning due to fluctuated high temperature during the growing period.

\section{Photothemal unit (PTU)}

PTU was calculated for $R$. damascena crop during the season 2015-2016 and 2016-2017 and results are present in Table 2. For pruning to flower bud formation stage, PTU decreased with delay in pruning. Higher PTU were accumulated by variety Jwala $\left(11220.8{ }^{\circ} \mathrm{C}\right.$ days $\left.\mathrm{h}\right)$ and Himroz $\left(10469.8^{\circ} \mathrm{C}\right.$ days h) for early pruned plants (October 30 ) and it decreased with delay in pruning time. Damask rose crop accumulated $12680.0^{\circ} \mathrm{C}$ days $\mathrm{h}$ PTU with 144.8 days for variety Himroz and $13400.4^{\circ} \mathrm{C}$ days h with 151.0 days for variety Jwala till complete flower harvest (Table 2). Among the pruning time, the highest PTU was recorded with October 30 pruned plants $\left(16391.9^{\circ} \mathrm{C}\right.$ days $\left.\mathrm{h}\right)$ for completion of total vegetative growth period (Table 2). The results were in accordance with the studies of Eruola (2014). The variety Jwala accounted significantly higher PTU than Himroz at all phenophases of $R$. damascena during both the years.

\section{Helio-thermal unit (HTU)}

Accumulated HTU for the phenological stage for pruning to flower bud formation presented in Table 2. Like
GDD and PTU, HTU gradually decreased with the delay in pruning time. Early pruned plants indicated maximum accumulated HTU which was $6142.9^{\circ} \mathrm{C}$ days $\mathrm{h}$ for flower bud formation (Table 2) and $9870.2^{\circ} \mathrm{C}$ days $\mathrm{h}$ for complete flower harvest. Among the pruning times, HTU mostly decreased with delay in pruning time and increment in HTU value was accredited with early pruned plant for both the varieties. Data presented in Tables 2 showed that variety Jwala accumulated more heat units for phenological stage for pruning to complete flower harvest as compared to Himroz. Similar findings were observed by Kumar et al., (2012) in white clover which showed decreased HTU for different phenophases due to delayed sowing. Late pruning compelled the plants to complete each phenological stage with a shorter period of time resulting in decreased HTU.

\section{CONCLUSION}

Damask rose plants pruned on October 30 (early) took maximum calendar days for completion of different phenological stages. Late pruned plants (January 15) recorded less GDD, PTU, HTU, day length, BSS and rainfall for each phenological stage viz., pruning to flower bud formation and complete flower harvest. Late pruning of 
Table 2: Agroclimatic indices during pruning to flower bud formation and pruning to complete flower harvest stage of $R$. damascena varieties (Pooled data of two years).

\begin{tabular}{|c|c|c|c|c|c|c|}
\hline \multirow[t]{2}{*}{ Pruning Time } & \multicolumn{3}{|c|}{ Pruning to flower bud formation } & \multicolumn{3}{|c|}{ Pruning to complete flower harvest stage } \\
\hline & AGDD & APTU & AHTU & AGDD & APTU & AHTU \\
\hline \multicolumn{7}{|c|}{ Himroz } \\
\hline October 30 & 996 & 10469 & 5733 & 1363.0 & 15305.3 & 9243.7 \\
\hline November 15 & 895 & 9422 & 5159 & 1281.3 & 14578.2 & 8695.1 \\
\hline November 30 & 865 & 9179 & 5022 & 1205.0 & 13743.3 & 8132.7 \\
\hline December 15 & 722 & 7894 & 4308 & 1015.4 & 11845.3 & 6681.0 \\
\hline December 30 & 599 & 6629 & 3614 & 891.3 & 10580.2 & 5761.0 \\
\hline January 15 & 476 & 5322 & 2899 & 823.9 & 10027.7 & 5347.2 \\
\hline Mean & 759 & 815 & 4456 & 1096.6 & 12680.0 & 7310.1 \\
\hline \multicolumn{7}{|c|}{ Jwala } \\
\hline October 30 & 1056 & 11220 & 6142 & 1441.1 & 16391.9 & 9870.2 \\
\hline November 15 & 939 & 9982 & 5460 & 1335.2 & 15328.9 & 9018.4 \\
\hline November 30 & 914 & 9820 & 5367 & 1258.8 & 14493.8 & 8538.0 \\
\hline December 15 & 739 & 8105 & 4422 & 1068.2 & 12581.7 & 7115.9 \\
\hline December 30 & 624 & 6965 & 3795 & 944.1 & 11316.8 & 6198.1 \\
\hline January 15 & 536 & 5975 & 3255 & 842.6 & 10289.1 & 5507.8 \\
\hline Mean & 801 & 8679 & 4740 & 1148.3 & 13400.4 & 7708.1 \\
\hline
\end{tabular}

Note: AGDD: Accumulated growing degree days; APTU: Accumulated photothermal unit; AHTU: Accumulated heliothermal unit

damask rose has taken the advantage of optimum temperature and sunlight during the stages of plant development and thereby avoided adverse situation during the complete phenological stage for pruning to complete flower harvest. Among the varieties, Jwala took highest calendar days, accumulated higher GDD, PTU and HTU from pruning to complete flower harvest. Agro-meteorological variables influenced the yield parameters and yield of $R$. damascena. Temperature, day length and BSS play an important role in determining the productivity of damask rose crop. The variations in the agro-meteorological indices give the information related to the effect of temperature and solar radiation on phenological stages and productivity in $R$. damascena. We can conclude that agro-meterological indices were calculated for the first time for damask rose crop and these can be used at other regions that have similar climatic conditions for yield forecasting.

\section{ACKNOWLEDGEMENT}

The authors are grateful to the Director, CSIR-IHBT, Palampur for providing necessary facilities during the course of study. Financial grant received from Department of Science and Technology (SB/S4/AS-134/2013), GOI, New Delhi is also acknowledged. This is IHBT publication number 4157 .

\section{REFERENCES}

Blacker, M. 1995. Roses for every Garden. ACP Publishing, London, UK.

Brar, S.K., Gill, B.S. and Brar, A.S. (2015). Effect of date of planting and harvesting schedule on heat-unit accumulation and biomass production in Japanese mint (Menthaarvensis). Ind. J. Agron. 60 (2): 324-327.

Calatayud, A., Roca, D., Gorbe, E. and Martinez, P.F. (2007). Light acclimation in rose (Rosa hybrida cv. Grand Gala) leaves after pruning: Effects on chlorophyll a fluorescence, nitrate reductase, ammonium and carbohydrates. Sci. Hortic. 111(2): 152-159.

Eruola, A., Ufogbune, G., Makinde, A. and Kassim, H. (2014). Effect of planting season on phenologyand accumulated heat units in relation to yield of white yam in the tropical 
wet- and-dry climate. Jordan J. Agric. Sci. 10(4): 758770 .

Kumar, R., Ramesh, K., Singh, R.D. and Prasad, R. (2010). Modulation of wild marigold (Tagetesminuta L.) phenophases towards the varying temperature regimesa field study. J. Agrometeorol., 12(2): 234-240.

Kumar, R., Ramesh, K., Tehria, S., Singh, B. and Prasad, R. (2010). Crop weather interaction studies in a natural sweetener plant (Stevia rebaudiana (Bert.) Bertoni) in Indian Western Himalaya. In Proceedings of the 7th Conference on Biometeorologyheld at Albert Ludwigs UniversityofFreiburg, Germany from 12-14April 2010: 38-43.

Kumar, R., Kaundal, M., Vats, S.K. and Kumar, S. (2012). Agrometerological indices of white clover (Trifolium repens) in Western Himalayas. J. Agrometeorol., 14(2): 138-142.
Malhotra, R. and Kumar, R. (2000). Effect of pruning height, shading and polythene covering on growth and flower production of rose cv. Raktagandha. J. Orna. Hort. 3(2): 94-99.

Mattson, N.S. and Lieth, J.H. (2007). The effect of temperature on year-round development of rose shoots initiated using cutting or bending. Acta Hort. 751: 121-128.

Paul, T.M., Siddique, M.A.A. and John, A.Q. (1995). Effect of severity and time of pruning on growth and flower production of Rosa damascena Mill. An important aromatic plant. Adv. Plant Sci.8: 28-32.

Thavaprakaash, N., Jagannathan, R., Velayudham, K. and Gurusamy,L. (2007). Seasonal influence on phenology and accumulated heat units in relation to yield of baby corn. Int. J. Agric. Res. 2(9): 826-831.

Zekavati, H.R. and Zadeh, A.A. (2013). Effect of time and type of pruning on the growth characteristics of rose. Int. J. Agric. Crop Sci. 6(11): 698-703. 